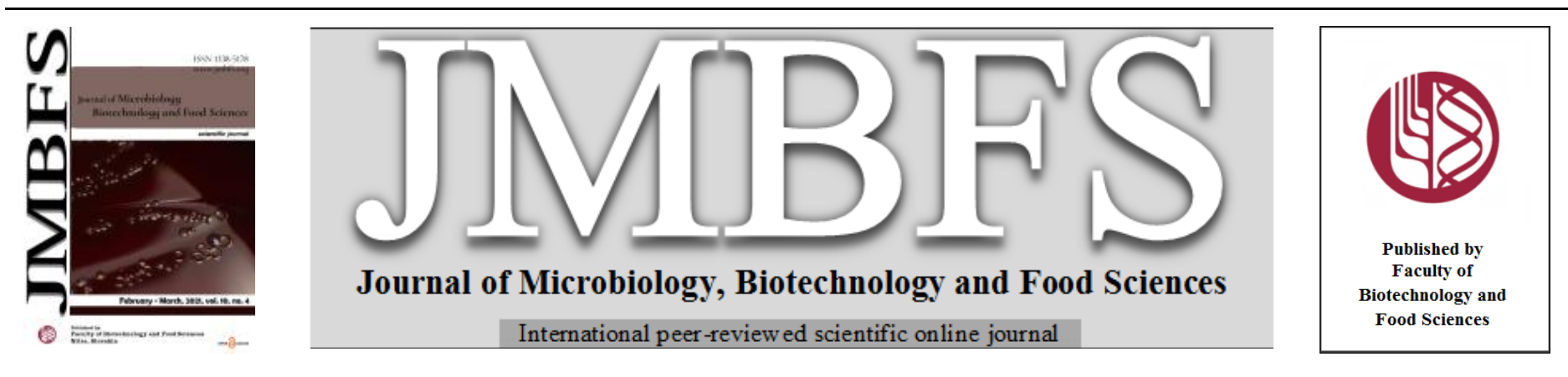

\title{
BIOCHEMICAL CHARACTERIZATION OF VEGETABLES WASTES AND DEVELOPMENT OF FUNCTIONAL BREAD
}

\author{
Muhammad Saad Hashmi ${ }^{1}$, Saeed Akhtar ${ }^{1}$, Tariq Ismail ${ }^{1}$ \\ Address(es): Dr. Tariq Ismail, \\ ${ }^{1}$ Institute of Food Science \& Nutrition, Bahauddin Zakariya University, 60800, Multan, Pakistan.
}

*Corresponding author: ammarbintariq@yahoo.com

doi: 10.15414/jmbfs.2021.10.4.691-696

ARTICLE INFO

Received 5.7. 2020

Revised 2. 11. 2020

Accepted 9. 11. 2020

Published 1. 2. 2021

\section{Regular article}

OPEN $\partial_{\text {ACCESS }}$

\begin{abstract}
The present study aimed at evaluating nutritional potential and antioxidant activity of the extracts derived from vegetable wastes such as carrot pomace, onion upper bulbs, and peels from garlic, tomato \& potato. Proximate composition, minerals profiling and antioxidants activity as 2,2-diphenyl-1-picrylhydrazyl (DPPH) and trolox equivalent antioxidant capacity (TEAC) were estimated, and phenolics characterization was performed using high performance liquid chromatography (HPLC). Our results suggest that vegetable wastes such as peel and pomace, may be exploited as carriers of proteins, fiber, calcium, potassium, iron and zinc. Phenolics screening demonstrated presence of total hydroxybenzoic, hydroxylcinammic acids and catechin albeit anthocyanins and total flavonols were inadequately present in tomato pomace. Maximum total phenolics contents and DPPH activity were observed in $\mathrm{HCl} / \mathrm{MeOH}$ extracts of tomato and garlic peels, respectively. Product development data suggest incorporating onion peel's extracts in wheat flour to not elicit a significant change in bread composition. Likewise, supplementation of onion peel powder (OPP) and extracts @ 6\% and 1.5\%, respectively improved color and textural properties of supplemented bread. Contextualizing the challenges of food insecurity and food industry waste management, our results confirmed that vegetable wastes, with improved nutritional profile and increased antioxidant potential, may be used for the preparation of value-added food products.
\end{abstract}

Keywords: Carrot pomace, Flavonoids, Functional bread, Onion peel, Potato peel, Vegetables waste

\section{INTRODUCTION}

Food waste has now been considered as an issue of economic significance and a substantial level of importance is associated worldwide to profit from it in terms of ensuring food security and mitigating environmental threats. Food and Agriculture Organization (FAO) enunciated food waste as global issue engendering food insecurities especially in lower-middle-income countries (FAO, 2019). Vegetable wastes are indiscriminately wasted without exploring their biochemical composition and food value. A plethora of studies have confirmed vegetable wastes being rich in macro and micro biomolecules, calling for nutritional characterization of such wastes for their utilization as ingredients of choice in the development of novel nutritional recipes (Bello et al., 2013). For example, red onion skin, tomato peel and seeds have been shown to hold high concentration of carbohydrates, total sugars, protein, fiber, ascorbic acid, trace elements, essential amino acids, biomolecules including flavonols, quercetin, diallylsulfide, thiosulfinate, fructans and anthocyanins (Knoblich et al., 2005; Bhattacharjee et al., 2013; Ogbonna et al., 2016; Dinkecha and Muniye, 2017). Nour et al. (2013) in their study explicated tomato pomace as carrier of good quality plant proteins, unsaturated fats, fiber, protein, and mineral element. Estimates indicate that vegetable wastes constitutes $24 \%$ of the total global food wastage out of which $54 \%$ wastage takes place during post-harvest and storage while $46 \%$ in processing and distribution. In this context, a variety of vegetable waste including edible seeds, skin, peel, pomace and their bioactive fractions have been suggested as ingredient of choice for food value addition on account of their promising nutritional and health promoting properties (Espinosa-Alonso et al., 2020). Vegetables and their wastes are known to be important sources of phytochemicals carotenoids, ascorbates and phenolics acid that may exert significant health benefits to the consumers being ameliorative against inflammation, cancer, high blood pressure, diabetes, coronary heart diseases, microbiological and parasitic infections, spasmodic conditions, psychotic diseases and ulcers (Dillard et al., 2000; Percival et al., 2006; Laura et al., 2009).

A number of vegetables wastes contain considerable amount of antioxidants viz natural bioactive compounds including phenolic compounds e.g., flavonoids, curcumanoids, coumarins, tannins, xanthons, terpenoids and lignans which belong to various parts of plants (Iqbal et al., 2008). Nour et al. (2018) and Beatrice and Ifesan (2017) reported varied levels lycopene, $\beta$-carotene, phenolics (chlorogenic and ellagic acids) and flavonoids (rutin and myricetin) in different part of vegetables wastes including carrots pomace, onion, tomato and potato peel extracts (De-Sotillo et al., 1994; Elbadrawy and Sello, 2016). Diverse bioactive chemical composition of the peel and pomace of the common culinary spices thus exhibit appreciable hypoglycemic, anti-inflammatory and anti-diabetic properties (Ichikawa et al., 2003; Ziamajidi et al., 2017). Garlic and its peel fractions are good source of organosulfur. Studies suggest garlic and its by-products consumption to elicit antioxidant, anti-inflammatory and antitumor activities while a lot has already been published on anticancer properties of organosulfur (Zhang et al., 2020). Allyl derivatives of organo-sulfur compounds as intrinsic antioxidants have been reported in garlic that may further extend their chemo-preventive role against degenerative disorders (Murakami et al., 2008) Nutritional composition of vegetables by-products / waste produced from vegetables processing indicate higher concentration of plant based dietary fiber (Silva et al., 2016). Adequate consumption of plant derived dietary fibers vide value addition and enrichment enable consumers to cope with the emerging health challenge (Yoon $\boldsymbol{e t}$ al., 2005). Considerably higher levels of fiber ranging between $61-125 \mathrm{~g} \cdot \mathrm{kg}^{-1}$ peel of various potato cultivars have reported in different researches (Gumul et al., 2011; Ncobela et al., 2017). According to Silva et al. (2016) each $100 \mathrm{~g}$ tomato pomace is known to contain about $51 \mathrm{~g}$ of dietary fibers. Fiber contents in onions varied from 3.8 to $5.2 \%$ while onion's outer skin exhibit 27\% dietary fiber (Bello et al., 2013; Dinkecha and Muniye, 2017).

Considerable nutritional and therapeutic role of vegetable waste and their extracts warrants their sagacious application in a variety of food products to subside regional food insecurity besides achieving the objective of mitigating environmental threats associated with increased generation of food wastes. The objective of the present study was exploring the possibilities to utilize selected vegetable wastes for the production of value-added and healthy food product vide screening nutritional profile of vegetables waste and bioactive compounds quantification. 


\section{MATERIALS AND METHODS}

\section{Procurement and preparation of raw materials}

Potato peel, garlic peel, tomato peel and seeds, carrot pomace and onion upper bulb with first two layers were procured as waste from the local vegetables and spices processing industries of Multan, Pakistan. Vegetable wastes were washed in potable water and oven dried at $50^{\circ} \mathrm{C}$ to a final moisture content of $\sim 8.0 \%$. Dried samples were converted to fine powders in kitchen grinder and subsequently stored at $4-6 \pm 2{ }^{\circ} \mathrm{C}$ in air tight glass jars for physicochemical characterization and value added product development.

\section{Proximate composition of vegetable wastes}

Proximate composition i.e., moisture (method no. 925.10), ash (method no. 923.03), fiber (method no. 32-10), protein (method no. 920.87), fat (method no. 920.85) and nitrogen free extract, and mineral profile of the vegetables wastes were determined by following the AOAC methods described by Latimer $\mathbf{~ J r}$ (2019).

\section{Extraction of dietary fibers and phenolics}

Dietary fibers were extracted from the vegetable wastes in accordance with the method followed by Plaza et al. (2010). Residues were dried to obtain insoluble dietary fiber fractions, while total dietary fibers (TDF) and soluble dietary fibers (SDF) were extracted using gravimetric and enzymatic method as adopted by Prosky et al. (1988). Extraction of the vegetables wastes for antioxidant rich fractions were performed using various hydro-alcoholic combinations i.e., $\mathrm{HCl}$ methanol (70:30), methanol $(70 \%, \mathrm{v} / \mathrm{v})$, acetone $(70 \%, \mathrm{v} / \mathrm{v})$ and ethanol $(70 \%$ $\mathrm{v} / \mathrm{v}$ ) at 70:30 solvent : distilled water ratio. Continuous homogenous mixing was performed in orbital shaker at $40^{\circ} \mathrm{C}$ for $2 \mathrm{hrs}$. The liquid mixtures were subjected to filtration using Whatman filter paper no. 41. Subsequently, permeates were concentrated at $40^{\circ} \mathrm{C}$ using rotary evaporator (Heidolph, Hei-Vap, Germany) and kept at $-80^{\circ} \mathrm{C}$ (Sanyo, MDF-U32V, Japan) for performing antioxidant assays, phenolics characterization and application in product development.

\section{Estimation of total phenolic contents (TPC)}

All extracts of the vegetable wastes were analyzed for total phenolic contents by adopting the method followed by Li et al. (2006) with modifications. Sample absorbance was measured against gallic acid standard $(10-100 \mathrm{ppm})$. Dried pee extracts were reconstituted by mixing extracts with the relevant solvents. $0.5 \mathrm{~mL}$ of the extracts solution was subjected to mixing into tubes containing 10 fold diluted, $2.5 \mathrm{~mL}$ Folin Ciocalteu Reagent (FCR) reagent. Test tube contents were further mixed with sodium carbonate $(2 \mathrm{~mL}, 7.5 \%)$. The reaction mixture was subjected to incubation for $30 \mathrm{~min}$ at $25^{\circ} \mathrm{C}$ and total phenolic contents were quantified by measuring absorbance at $760 \mathrm{~nm}$ using UV-Vis spectrophotometry (UV-Vis 3000, ORI, Germany). Gallic acid was used as standard and data were computed as mg of gallic acid equivalent (mgGAE) equivalent per $100 \mathrm{~g}$ of the sample.

\section{Characterization of Phenolic Compounds}

Phenolic compounds extracted from vegetables waste were characterized on high performance liquid chromatography according to the procedure laid down by Penarrieta et al. (2008).

\section{Preparation of samples for HPLC analysis}

Two gram of dehydrated vegetables waste samples were weighed onto an analytical weighing balance and extracts were recovered by using distilled water. Water extracts were subjected to moist heating in water bath (GLS Aqua 12 plus) at $40^{\circ} \mathrm{C}$, centrifuged at $2500 \mathrm{rpm}$ for $10 \mathrm{~min}$ and filtered using Whatman filter paper no. 1 .

\section{HPLC Analysis and phenolics quantification}

Identification and quantification of the vegetable wastes extracts were performed by UFLCXR system (Shimadzu) equipped with photodiode array (SPD-20A) accompanied with binary pump and a solvent delivering module (LC-20AD). The whole set of equipment was also attached with a degasser (DGU-20A3/A5) and thermostat auto-sampler (SIL- 20A). Photodiode detector of HPLC was fixed to estimate the values at successive wavelengths i.e., $265 \mathrm{~nm}, 280 \mathrm{~nm}, 320 \mathrm{~nm}, 360$ $\mathrm{nm}$, and $520 \mathrm{~nm}$. Gradient system was adjusted at mobile phase of $0.1 \%(\mathrm{v} / \mathrm{v})$ trifluoroacetic acid (A). Water, acetonitrile and Trifluoroacetic acid were used as mobile phase $\mathrm{B}$ at a ratio of 0.1:49.9:50.

Chromatographic segregation of compounds was done at Phenomenex Gemin C18 column with dimensions of $250 \mathrm{~mm} \times 4.6 \mathrm{~mm}$ and flow rate was set at $1 \mathrm{~mL} \cdot \mathrm{min}^{-1}$. Column temperature was set at $35^{\circ} \mathrm{C}$. Injection of sample was adjusted to $10 \mu \mathrm{L}$. Phenolics identification in samples of vegetable wastes extracts were performed on the basis of comparison of sample values to that of standards used for phenolics at same operating conditions set for HPLC and LC-MS.

Determination of antioxidant activity

Determination of 2,2-diphenyl-1-picrylhydrazyl (DPPH) free radical scavenging activity

DPPH antioxidant potential of vegetables powder based extracts was estimated in accordance with the method adopted by Singh $\boldsymbol{e t}$ al. (2009). Vegetable waste extracts were prepared with concentrations in range between 50 to $100 \mathrm{ppm}$. 50 $100 \mu \mathrm{L}$ of prepared extracts was taken into pre labeled test tubes. Test tube volume was adjusted to $100 \mu \mathrm{L}$ by adding methanol. Five milliliter freshly prepared DPPH reagent $(0.1 \mathrm{mM})$ was drawn in each test tube and mixed with the samples. Mixture samples were incubated at room temperature for a period of 30 min for reaction. Control sample was prepared without extracts and absorbance readings of sample and control were recorded at $517 \mathrm{~nm}$ (UV-Vis 3000, ORI Germany). DPPH free radical scavenging activities were calculated using below mentioned formula: -

$$
\text { Radical scavenging activity }(\%)=\frac{\text { Control OD }- \text { Sample OD }}{\text { Control OD }} \times 100
$$

\section{Trolox equivalent antioxidant capacity (TEAC) assay}

TEAC assay works on 2,2-azinobis-3-ethylbenzothiazoline-6-sulfonic acid (ABTS) radical reduction principle wherein antioxidants in samples reduces ABTS radical cations. Assay was performed in accordance with the method followed by Agourram et al. (2013). ABTS (7 mM) was oxidized with potassium persulfate $(2.45 \mathrm{mM})$. Reagents were incubated for a period of $\sim 15 \mathrm{hrs}$ at room temperature prior use. The stock solution was diluted to an absorbance concentration of 0.700 and equilibrated at $30^{\circ} \mathrm{C}$. Blank reading was measured at $734 \mathrm{~nm}$ (UV-Vis 3000, ORI, Germany). Three milliliter of ABTS diluted solution was drawn in a test tube carrying $30 \mu \mathrm{l}$ vegetables waste extracts. Test tube contents were mixed and absorbance reading was taken exactly after 6 min of mixing. ABTS radical scavenging activity was measured using following formula:

$$
\% \text { inhibition }=\left(\mathrm{A}_{\text {blank }}-\mathrm{A}_{\text {sample }}\right) / \mathrm{A}_{\text {blank }} \times 100
$$

\section{Product Development}

Vegetables wastes screened for their soluble and insoluble fiber contents were further scrutinized for product development on the basis of maximum fiber contents. Standard recipe of the bread formulated by supplementing the waste fraction (powder \& extracts) is given in Table- 1

Table 1 Treatment combinations for the preparation of OSP and OSPE supplemented bread

\begin{tabular}{lccccccccc}
\hline Recipe & $\begin{array}{c}\text { Flour } \\
(\%)\end{array}$ & $\begin{array}{c}\text { Sugar } \\
(\%)\end{array}$ & $\begin{array}{c}\text { Yeast } \\
(\%)\end{array}$ & $\begin{array}{c}\text { Oil } \\
(\%)\end{array}$ & $\begin{array}{c}\text { Salt } \\
(\%)\end{array}$ & $\begin{array}{c}\text { CP } \\
(\%)\end{array}$ & $\begin{array}{c}\text { BP } \\
(\%)\end{array}$ & $\begin{array}{c}\text { OSP } \\
(\%)\end{array}$ & $\begin{array}{c}\text { OSPE } \\
(\%)\end{array}$ \\
\hline T0 & 100 & 10 & 2.0 & 1.5 & 1,0 & 0.6 & 0.3 & 0.0 & 0.0 \\
T1 & 98.0 & 10 & 2.0 & 1.5 & 1,0 & 0.6 & 0.3 & 2.0 & 0.0 \\
T2 & 96.0 & 10 & 2.0 & 1.5 & 1,0 & 0.6 & 0.3 & 4.0 & 0.0 \\
T3 & 94.0 & 10 & 2.0 & 1.5 & 1,0 & 0.6 & 0.3 & 6.0 & 0.0 \\
T4 & 99.5 & 10 & 2.0 & 1.5 & 1,0 & 0.6 & 0.3 & 0.0 & 0.5 \\
T5 & 99.0 & 10 & 2.0 & 1.5 & 1,0 & 0.6 & 0.3 & 0.0 & 1.0 \\
T6 & 98.5 & 10 & 2.0 & 1.5 & 1,0 & 0.6 & 0.3 & 0.0 & 1.5 \\
\hline
\end{tabular}

OSP: Onion Skin Powder, OSPE: Onion Skin Powder extracts BP: Baking

Powder, CP; Calcium Propionate:

$T_{0}$ indicate the normal control i.e., $100 \%$ wheat flour. $T_{1}, T_{2}$ and $T_{3}$ represents onion peel powder supplementation at the rate of 2,4 and $6 \%$, respectively while $T_{4}, T_{5}$, and $T_{6}$ are treatments supplemented with onion skin extracts @ 0.5, 1.0 and $1.5 \%$, respectively.

\section{Preparation of bread}

Bread ingredients including flour, salt, sugar, oil and yeast were mixed for 20 min. with potable water in a spiral mixer to convert contents into the stable dough. The dough thus developed was subjected to fermentation at $27 \pm 2^{\circ} \mathrm{C}$ for 50 min. Dough was shaped and molded into the pans and proofing was performed at $45 \pm 5^{\circ} \mathrm{C}$ for $45 \mathrm{~min}$ at $85 \%$ relative humidity. Subsequently, the proofed dough after gaining appropriate height were subjected to baking at $230 \pm 5^{\circ} \mathrm{C}$ for $20-30$ min. Baked breads were cooled at $40 \pm 2^{\circ} \mathrm{C}$ for 15 min., sliced, packed in polyethylene bags and stored for further analysis (Korus et al., 2015).

\section{Sensory evaluation}

Bread thus produced was subjected to sensory evaluation by a panel of 15 sensory experts from Institute of Food Science and Nutrition, Bahauddin 
Zakariya University, Multan. Nine-point hedonic scale was implemented for the sensory quality assessment of the bread. The hedonic scale varied at 1- dislike extremely to 9- like extremely. Sensory evaluation protocols were followed that also include training experts to not eat any food well before sensory evaluation to avoid biasness. Proper care was taken to ensure adequate supply of light in sensory evaluation chambers to eliminate risk of false color reading (Akhtar $\boldsymbol{e t}$ al., 2008).

\section{Statistical analysis}

Data were statistically analyzed using analysis of variance (ANOVA) technique on CoStat and Statistix software with three replicates of each measurement and results were presented as means \pm S.D. Least significance difference (LSD) was computed and level of significance was set as $p<0.05$

Table 2 Proximate composition of the vegetables wastes (g. $100 \mathrm{~g}^{-1}$ d.w.)

\section{RESULTS AND DISCUSSION}

\section{Nutritional composition of vegetables' waste}

Data presented in Table 2 indicate different vegetable wastes to be significantly varying $(p<0.05)$ in concentration for moisture, ash, protein, fat, crude fiber and NFE with a few exceptions. For instance, moisture level and ash content in garlic and tomato peel appeared to be the same $(p>0.05)$ while protein content did not significantly differ in onion and potato peel. Likewise, onion peel was shown to non-significantly differ in fat, crude fiber and NFE with carrot pomace, garlic and tomato peels respectively (Table-1). Our results depicted the highest concentration of ash in carrot pomace $(6.4 \pm 0.20 \%)$ followed by onion $(5.2 \pm 0.30 \%)$ and tomato peel $(4.3 \pm 0.10 \%)$. Relative concentration of protein $(10.7 \pm 0.40 \%)$ and fat $(4.6 \pm 0.53 \%)$ was much higher in tomato peel whereas crude fiber was available in the highest proportions in carrot pomace $(12.7 \pm 0.75 \%)$ and potato peel $(12.1 \pm 0.74 \%)$.

\begin{tabular}{lcccccc}
\hline Waste Products & Moisture & Ash & Protein & Fat & Crude Fibre & NFE \\
\hline Carrot Pomace & $4.20 \pm 0.1^{\mathrm{c}}$ & $6.44 \pm 0.20^{\mathrm{a}}$ & $1.30 \pm 0.05^{\mathrm{c}}$ & $1.55 \pm 0.10^{\mathrm{c}}$ & $12.74 \pm 0.75^{\mathrm{a}}$ & $73.79 \pm 3.34^{\mathrm{d}}$ \\
Garlic peel & $5.23 \pm 0.3^{\mathrm{b}}$ & $0.63 \pm 0.01^{\mathrm{e}}$ & $0.76 \pm 0.00^{\mathrm{d}}$ & $0.13 \pm 0.06^{\mathrm{d}}$ & $0.60 \pm 0.94^{\mathrm{e}}$ & $92.66 \pm 3.90^{\mathrm{a}}$ \\
Onion Peel & $8.72 \pm 0.5^{\mathrm{a}}$ & $5.19 \pm 0.30^{\mathrm{b}}$ & $2.47 \pm 0.03^{\mathrm{b}}$ & $1.49 \pm 0.54^{\mathrm{c}}$ & $6.90 \pm 0.68^{\mathrm{c}}$ & $75.24 \pm 2.03^{\mathrm{c}}$ \\
Potato Peel & $3.38 \pm 0.2^{\mathrm{d}}$ & $1.75 \pm 0.40^{\mathrm{d}}$ & $2.45 \pm 0.07^{\mathrm{b}}$ & $2.69 \pm 0.12^{\mathrm{b}}$ & $12.05 \pm 0.74^{\mathrm{b}}$ & $77.70 \pm 2.58^{\mathrm{b}}$ \\
Tomato Peel & $5.59 \pm 0.2^{\mathrm{b}}$ & $4.26 \pm 0.10^{\mathrm{c}}$ & $10.7 \pm 0.40^{\mathrm{a}}$ & $4.57 \pm 0.53^{\mathrm{a}}$ & $4.05 \pm 0.11^{\mathrm{d}}$ & $70.85 \pm 1.11^{\mathrm{e}}$ \\
\hline
\end{tabular}

Means $\pm S D$; Values sharing same lettering in a column do not differ significantly at $p<0.05$; NFE $=$ Nitrogen Free Extract

Vegetables peel and pomace are good reservoirs of inorganic substances and it was evidently identified from the ash contents wherein carrot pomace, onion and tomato peel were carrying significantly different $(\mathrm{p}<0.001)$ ash contents in range between $4.3-6.4 \%$. Various studies have demonstrated levels of different food components in a variety of vegetable wastes. These reports suggest vegetable wastes to be rich in basic food components e.g., Elbadrawy and Sello (2016) illustrated the levels of proteins and inorganic residues in potato peel at $10.5 \%$ and $\sim 6 \%$, respectively which is in close proximity with the level of proteins and ash contents in our study (Table 2). Our results are in line with those of Gull $\boldsymbol{e t}$ al. (2015) who reported $11.7 \%$ crude fiber and $7 \%$ ash in carrot pomace powder while we reported $\sim 12 \%$ fiber and $6.44 \%$ ash contents. Sharma et al. also found higher amount of protein $(10.1 \%)$ in carrot pomace (Sharma et al., 2016). Comparing our results with Jaime et al. (2002) for fiber contents in onion peel, the levels for fiber contents differed significantly with those reported in our studies which may be attributed to the varietal difference. Cooking and processing operations including blanching and freezing have shown significant losses in protein, fat, ash and mineral contents of the vegetables' waste which in turn suggests sagacious utilization of such waste to meet emerging risks of food insecurities (Florkiewicz et al., 2014).

\section{Minerals composition of vegetables' waste}

Data on composition of minerals in selected vegetable wastes have been presented in Table 3 and are suggestive of substantial variance $(p<0.05)$ in concentration of minerals among samples. Potato peel was found to hold increasingly high level of calcium $\left(790 \pm 2.9 \mathrm{mg} \cdot \mathrm{kg}^{-1}\right)$ and sodium $(513 \pm 0.4$ mg. $\left.\mathrm{kg}^{-1}\right)$ whilst tomato peel exhibited increased concentration of iron $(6.2 \pm 0.2$ mg. $\left.\mathrm{kg}^{-1}\right)$ and zinc $\left(8.4 \pm 0.5 \mathrm{mg} \cdot \mathrm{kg}^{-1}\right)$ relative to other vegetable wastes Considerable amount of potassium $\left(1207 \pm 2.0 \mathrm{mg} \cdot \mathrm{kg}^{-1}\right)$ was noted in carrot pomace. Irrespective of the highest and lowest levels of specific mineral in these vegetable wastes, tomato peel had indicated a balanced composition for all tested minerals i.e. calcium, sodium, potassium, iron and zinc (Table-3)

Table 3 Minerals composition of selected vegetables wastes $\left(\mathrm{mg} \cdot \mathrm{kg}^{-1}\right)$

\begin{tabular}{llllll}
\hline Vegetable Waste & Calcium & Sodium & Potassium & Iron & Zinc \\
\hline Carrot Pomace & $407 \pm 1.63^{\mathrm{c}}$ & $332 \pm 1.34^{\mathrm{b}}$ & $1207 \pm 1.99^{\mathrm{a}}$ & $4.74 \pm 0.11^{\mathrm{b}}$ & $3.47 \pm 0.01^{\mathrm{b}}$ \\
Garlic peel & $174 \pm 0.79^{\mathrm{d}}$ & $26 \pm 1.09^{\mathrm{d}}$ & $478 \pm 0.64^{\mathrm{d}}$ & $3.75 \pm 0.15^{\mathrm{c}}$ & $0.27 \pm 0.03^{\mathrm{e}}$ \\
Onion Peel & $37 \pm 0.24^{\mathrm{e}}$ & $3.81 \pm 0.14^{\mathrm{e}}$ & $14.5 \pm 0.14^{\mathrm{e}}$ & $1.75 \pm 0.06^{\mathrm{e}}$ & $2.34 \pm 0.01^{\mathrm{c}}$ \\
Potato Peel & $790 \pm 2.87^{\mathrm{a}}$ & $513 \pm 0.40^{\mathrm{a}}$ & $935 \pm 0.59^{\mathrm{b}}$ & $3.35 \pm 0.37^{\mathrm{d}}$ & $2.11 \pm 0.03^{\mathrm{d}}$ \\
Tomato Peel & $428 \pm 0.09^{\mathrm{b}}$ & $188.5 \pm 0.08^{\mathrm{c}}$ & $860.5 \pm 0.08^{\mathrm{c}}$ & $6.19 \pm 0.24^{\mathrm{a}}$ & $8.43 \pm 0.53^{\mathrm{a}}$ \\
\hline
\end{tabular}

Means $\pm S D ;$ Values sharing same lettering in a column do not differ significantly at $p<0.05$

Minerals and trace element have been known to elicit beneficial effects on human health being integral part of human metabolism. These valuable food ingredients are predominantly lost with vegetable wastes during production and processing which exacerbates the environmental threats and food insecurity issues. Our study (Table 3) validated vegetable wastes to hold considerably higher amounts of minerals and trace element. Adeola et al. (2017) reported $\sim 8$ ppm iron, 3.5 ppm zinc and $4.7 \mathrm{ppm}$ in carrot pomace powder and these levels are comparable with our results for iron and zinc concentration (Table 3). Zoair et al. (2016) reported potato peel to hold $\sim 1600 \mathrm{mg} \cdot \mathrm{kg}^{-1} \mathrm{Ca}$ and $590 \mathrm{mg} \cdot \mathrm{kg}-1 \mathrm{Na}$ that is at higher side when compared with the recent findings which may be ascribed with varieties and experimental conditions. More recent studies have corroborated the presence of higher amounts of mineral elements including potassium, calcium, magnesium iron and zinc in various cultivars of potato peels suggesting potato peels to be a valuable vegetable waste for its utilization in various food preparations (Dusuki et al., 2019; Vaitkevičienè, 2019).

\section{Phenolics characterization of vegetables' waste}

Chromatographic characterization data for hydroxybenzoic acids (HBAs) of vegetables' waste extracts are shown in Table 4 . The data suggest tomato peel and carrot pomace as highest carrier of HBAs i.e., 383 and $162 \mathrm{mg}^{-100 \mathrm{~g}^{-1}}$ of the powder whereas least concentration of HBAs was noticed in garlic peel extracts i.e., $52 \mathrm{mg} .100 \mathrm{~g}^{-1}$. In addition to gallic acid, other known HBAs identified in vegetables waste powder extracts include hibiscus acid, hibiscus acid glucosides and protocatechuic acid. Maximum concentration of gallic acid, hibiscus acid glucosides and hibiscus acid were recorded in tomato and potato peel, respectively (Table 4). 
Table 4 Hydroxybenzoic acid (HBAs) derivatives in vegetables waste

\begin{tabular}{|c|c|c|c|c|c|c|c|c|}
\hline Compound & Peak & retention time & $\lambda_{\max }$ & Potato Peel & Tomato Peel & $\begin{array}{l}\text { Garlic } \\
\text { Peel }\end{array}$ & $\begin{array}{l}\text { Carrot } \\
\text { Pomace } \\
\end{array}$ & $\begin{array}{l}\text { Onion } \\
\text { Peel } \\
\end{array}$ \\
\hline Hibiscus acid & 2 & 4.6 & 265 & $65.0 \pm 12.6$ & $55 \pm 5.2$ & $8 \pm 2.2$ & $10 \pm 2.1$ & $10 \pm 2.3$ \\
\hline Gallic acid & 3 & 6 & 265 & $5 \pm 1.2$ & $50 \pm 4.4$ & $6 \pm 1.8$ & $8 \pm 1.0$ & $15 \pm 3.0$ \\
\hline Unidentified & 5 & 7.4 & 280 & $11 \pm 3.3$ & $40 \pm 3.5$ & $5 \pm 1.4$ & $89 \pm 6.6$ & $10 \pm 3.1$ \\
\hline Protocatechuic acid & 6 & 8.8 & 265 & $5 \pm 2.1$ & $18 \pm 2.9$ & $4 \pm 1.5$ & $20 \pm 2.3$ & $20 \pm 4.7$ \\
\hline Unidentified & 8 & 9.86 & 280 & $6 \pm 2.0$ & $16 \pm 3.1$ & $5 \pm 1.3$ & $4 \pm 1.0$ & $5 \pm 2.2$ \\
\hline
\end{tabular}

World has been facing environmental, economic and nutritional challenges owing to rampant loss of fruits and vegetables in addition to the generation of food processing waste. FAO estimates $60 \%$ of fruits and vegetables loss every year whereas processing fruits and vegetables leads to the production of about 25 $30 \%$ of waste as by product comprising pomace, skin, seed and rind. These fruits and vegetable wastes have been found to be the reservoirs of bioactive compounds carotenoids, phenolics, dietary fibers and with increased therapeutic and food values (Sagar et al., 2018). More recently, Ben-Othman et al. (2020) have comprehensively reviewed the opportunities and challenges for the potentia use of bioactive compound including HBAs in food preparation and other value added products. This approach is in-consistent with our research objectives set out in the present study.

Table 5 Hydroxycinnamic acid derivatives in vegetables' waste

\begin{tabular}{|c|c|c|c|c|c|c|c|c|}
\hline Compound & Peak & Retention time & $\lambda_{\max }$ & Potato Peel & Tomato Peel & $\begin{array}{l}\text { Garlic } \\
\text { Peel }\end{array}$ & $\begin{array}{l}\text { Carrot } \\
\text { Pomace }\end{array}$ & $\begin{array}{l}\text { Onion } \\
\text { Peel }\end{array}$ \\
\hline 3-O-caffeoylquinic acid & 7 & 9.2 & 320 & $5 \pm 2.0$ & $12 \pm 3.5$ & $0.2 \pm 0.2$ & $5 \pm 1.1$ & $5 \pm 1.5$ \\
\hline 4-O-caffeoylquinic acid & 10 & 10.8 & 320 & $5 \pm 1.7$ & $10 \pm 2.7$ & $0.2 \pm 0.1$ & 0 & 0 \\
\hline cis/tran caftaric acid & 11 & 11.6 & 309 & $5 \pm 2.0$ & $14 \pm 4.4$ & $1.6 \pm 0.8$ & $5 \pm 1.6$ & 0 \\
\hline cis/tran caftaric acid & 12 & 12.05 & 309 & $65 \pm 12.5$ & $14 \pm 3.6$ & $9.8 \pm 3.6$ & 0 & 0 \\
\hline Chlorogenic acid isomer & 14 & 13.15 & 320 & $10 \pm 2.6$ & $14 \pm 3.9$ & $3 \pm 1.2$ & 0 & $5 \pm 1.6$ \\
\hline 5-O-caffeoylquinic acid & 15 & 13.31 & 320 & $25 \pm 5.5$ & $14 \pm 2.8$ & $0.6 \pm 0.8$ & 0 & $5 \pm 1.2$ \\
\hline Caffeic acid & 18 & 15.22 & 320 & 0 & $14 \pm 3.6$ & 0 & 0 & $5 \pm 1.2$ \\
\hline Chlorogenic acid isomer & 21 & 16.37 & 320 & 0 & $14 \pm 3.5$ & $1.6 \pm 1.5$ & 0 & $10 \pm 2.5$ \\
\hline Cinnamic acid & 26 & 20.2 & 320 & 0 & $10 \pm 2.3$ & $3 \pm 1.5$ & $5 \pm 1.5$ & $10 \pm 3.2$ \\
\hline Coumeric acid & 27 & 20.8 & 320 & 0 & $8 \pm 2.5$ & $0.8 \pm 0.5$ & $10 \pm 3.3$ & 0 \\
\hline Ferulic acid & 29 & 22.3 & 320 & 0 & $8 \pm 2.6$ & $1.6 \pm 1.0$ & $5 \pm 1.6$ & 0 \\
\hline Total HA & & & & $115 \pm 15.9$ & $132 \pm 17.4$ & $22.4 \pm 6.3$ & $30 \pm 6.9$ & $40 \pm 10.4$ \\
\hline
\end{tabular}

Data derived from phytochemical characterization of vegetables' waste fractions revealed plausible concentration of hydroxycinnamic acids (HCAs) (Table 5). Highest mean concentration of HCAs was recovered from potato peel i.e., 115 mg. $100 \mathrm{~g}^{-1}$ followed by the peel and pomace fraction of tomato, onion, carrot and garlic i.e., $132,40,30,22 \mathrm{mg} .100 \mathrm{~g}^{-1}$, respectively.

Table 6 Anthocyanin, total flavanol, total flavan-3-ols contents of selected vegetables wastes

\begin{tabular}{|c|c|c|c|c|c|c|c|c|}
\hline 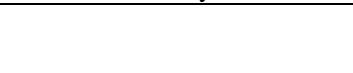 & Peak & $\begin{array}{l}\text { Retention } \\
\text { time }\end{array}$ & $\lambda \max$ & Potato Peel & Tomato Peel & $\begin{array}{l}\text { Garlic } \\
\text { Peel } \\
\end{array}$ & $\begin{array}{l}\text { Carrot } \\
\text { Pomace }\end{array}$ & $\begin{array}{l}\text { Onion } \\
\text { Peel }\end{array}$ \\
\hline \multicolumn{9}{|l|}{ Anthocyanin } \\
\hline delphinidin 3-O-glucoside & 17 & 14.6 & 520 & $2.2 \pm 0.4$ & 0 & 0 & $10 \pm 2.2$ & 0 \\
\hline cyanidin 3-O-glucoside & 20 & 15.79 & 520 & 0 & 0 & 0 & $2 \pm 0.4$ & 0 \\
\hline cyanidin 3-O-sambubio & 21 & 16.3 & 520 & 0 & 0 & 0 & $1 \pm 0.2$ & 0 \\
\hline \multicolumn{9}{|l|}{ Total flavanol } \\
\hline Myricetin 3-sambubioside & 25 & 19.7 & 360 & $0.2 \pm 0.0$ & $2 \pm 0.8$ & $0.25 \pm 0.1$ & $0.6 \pm 0.1$ & $25 \pm 5.5$ \\
\hline Quercetin 3-sambubioside & 27 & 22.4 & 360 & $0.2 \pm 0.1$ & 0 & $1.00 \pm 0.5$ & $0.2 \pm 0.0$ & $10 \pm 2.5$ \\
\hline Rutin & 30 & 23.9 & 360 & $0.4 \pm 0.1$ & 0 & 0 & 0 & $5 \pm 1$ \\
\hline Quercetin 3-glucoside & 31 & 24.8 & 360 & $0.2 \pm 0.0$ & 0 & 0 & $0.2 \pm 0.0$ & $10 \pm 2.0$ \\
\hline \multicolumn{9}{|l|}{ Total flavan-3-ols } \\
\hline Catechin & 13 & 12.88 & 280 & $23 \pm 3.6$ & $30 \pm 12.4$ & $5 \pm 1.0$ & 0 & $5 \pm 1.2$ \\
\hline
\end{tabular}

HCAs identified from the waste fractions include 3-O-caffeoylquinic acid, 4-Ocaffeoylquinic acid, cis/tran caftaric acid, chlorogenic acid isomer, 5-Ocaffeoylquinic acid, caffeic acid, chlorogenic acid isomer, cinnamic acid coumeric acid and ferulic acid. Tomato peel extracts were found to carry all identified bioactive compounds in a range between $8-14 \mathrm{mg} \cdot 100 \mathrm{~g}^{-1}$. Maximum concentrations of caffeic acid, chlorogenic acid, cinnamic acids and ferulic acid were observed in tomato peel while none of the mentioned compound was identified in potato peel extracts. Recent studies have explicated the occurrence of a series of phytochemicals (polyphenols and carotenoids) in vegetables wastes These bioactive compounds derived from vegetable by-products, have now drawn the attention of relevant industries for their significant health promoting features (Coman et al., 2020; Lu et al., 2019).

Phenolics characterization of selected vegetables indicated the presence of delphinidin 3-O-sambubioside, delphinidin 3-O-glucoside, cyanidin 3-Oglucoside and cyanidin 3-O-sambubio among known anthocyanins (Table 6). Peel and pomace extracts of potato, tomato, onion, garlic and carrot were found to hold trace levels of anthocyanins. Maximum concentration of anthocyanins was recorded from carrot pomace extracts i.e., $16 \mathrm{mg} .100 \mathrm{~g}^{-1}$ followed by potato peel extracts i.e., $\sim 5 \mathrm{mg} .100 \mathrm{~g}^{-1}$ while none of the above mentioned anthocyanins were identified in tomato, onion and garlic peel. Likewise, trace amount of flavanols were recorded from the peel and pomace fraction of potato, tomato, garlic and carrot. Appreciable amount of flavanols (50 mg.100g-1) including myricetin 3- sambubioside, quercetin 3-sambubioside, rutin and quercetin 3 glucoside were quantified from onion peel extracts (Table 6). Rutin is a low molecular weight phenolic compound that is synthesized more frequently in rind fraction of fruits like citrus and berries (Patel and Patel, 2019). Trace amount of rutin were identified in peel and pomace of various vegetables more prominently in onion peel wherein its concentration was recorded as $5 \mathrm{mg} .100 \mathrm{~g}-1$ of the powder. Among flavan-3-ols, catechin and four unidentified fractions were also recorded. Tomato, potato and onion peel extracts were found to hold 54, 43 and $25 \mathrm{mg} .100 \mathrm{~g}^{-1}$ of the flavan-3-ols, respectively. Maximum concentration of catechin was recorded in tomato peel i.e., $30 \mathrm{mg} 100 \mathrm{~g}^{-1}$ while garlic peel was found devoid of catechin (Table 6). Varied concentrations of flavan-3-ols in a range between $2-7 \mathrm{mg} .100 \mathrm{~g}^{-1}$ of fresh weight were reported by Harnly $\boldsymbol{e t}$ al. (2006) in different cultivars of vegetables including onion, potato and tomato. This further suggests differences in concentration of bioactive compounds to be more linked with type of vegetables, cultivar and anatomical fraction. Sarkar and Kaul (2014) explained differences in chemical composition of tomato seeds and peels suggesting tomato peel to be carrying higher concentrations of lycopene and beta-carotene and other phenolic compounds. Conclusively, 
polyphenolics characterization and quantification data of vegetables' waste including peel fraction of potato, tomato, onion and garlic, and pomace fraction of carrot as plausible source of hydroxycinnamic acids, hydroxybenzoic acids and flavan-3-ols that may further be exploited as purified nutraceutical preparation for prevention and management of a variety of health ailments.

Table 7 Effect of onion peel powder and extracts supplementation on bread internal characteristics

\begin{tabular}{|c|c|c|c|c|c|}
\hline Treatments & Grain & Colour of Crumb & Mastication & Taste & Aroma \\
\hline $\mathrm{T}_{0}$ & $8.13 \pm 0.30^{\mathrm{d}}$ & $7.96 \pm 0.23^{\mathrm{ab}}$ & $8.50 \pm 0.34^{\mathrm{a}}$ & $8.65 \pm 0.35^{\mathrm{a}}$ & $8.66 \pm 0.42^{\mathrm{a}}$ \\
\hline $\mathrm{T}_{1}$ & $8.33 \pm 0.27^{\mathrm{cd}}$ & $7.85 \pm 0.22^{\mathrm{ab}}$ & $8.47 \pm 0.26^{\mathrm{a}}$ & $8.52 \pm 0.28^{\mathrm{a}}$ & $8.52 \pm 0.28^{\mathrm{ab}}$ \\
\hline $\mathrm{T}_{2}$ & $8.19 \pm 0.35^{\mathrm{d}}$ & $8.18 \pm 0.24^{\mathrm{a}}$ & $7.29 \pm 0.48^{\mathrm{c}}$ & $8.23 \pm 0.51^{\mathrm{a}}$ & $8.47 \pm 0.21^{\mathrm{ab}}$ \\
\hline $\mathrm{T}_{3}$ & $8.83 \pm 0.23^{\mathrm{a}}$ & $8.17 \pm 0.35^{\mathrm{a}}$ & $5.82 \pm 0.23^{\mathrm{d}}$ & $7.59 \pm 0.22^{\mathrm{b}}$ & $8.09 \pm 0.30^{\mathrm{b}}$ \\
\hline $\mathrm{T}_{4}$ & $8.37 \pm 0.25^{\mathrm{b}-\mathrm{d}}$ & $7.64 \pm 0.23^{b}$ & $8.24 \pm 0.22^{\mathrm{a}}$ & $8.59 \pm 0.41^{\mathrm{a}}$ & $8.10 \pm 0.31^{\mathrm{b}}$ \\
\hline $\mathrm{T}_{5}$ & $8.66 \pm 0.16^{\mathrm{a}-\mathrm{c}}$ & $7.88 \pm 0.25^{\mathrm{ab}}$ & $7.79 \pm 0.45^{\mathrm{b}}$ & $7.16 \pm 0.43^{b c}$ & $7.56 \pm 0.45^{\mathrm{c}}$ \\
\hline $\mathrm{T}_{6}$ & $8.77 \pm 0.44^{\mathrm{ab}}$ & $6.95 \pm 0.16^{\mathrm{c}}$ & $7.37 \pm 0.20^{\mathrm{bc}}$ & $6.97 \pm 0.32^{\mathrm{c}}$ & $6.02 \pm 0.31^{\mathrm{d}}$ \\
\hline
\end{tabular}

Means $\pm S D ;$ Values sharing same lettering in a column do not differ significantly at $p<0.05$

$T_{0}$ indicate the normal control i.e., $100 \%$ wheat flour. $T_{1}, T_{2}$ and $T_{3}$ represents onion peel powder supplementation at the rate of 2 , 4 and $6 \%$, respectively while $T_{4}, T_{5}$, and $T_{6}$ are treatments supplemented with onion skin extracts @ 0.5, 1.0 and 1.5\%, respectively.

\section{Sensory evaluation of Onion skin powder and extracts supplemented bread}

Results presented in Table 7 showed that supplementation of onion skin powder (OSP) and onion skin powder extracts (OSPE) at various concentrations had significantly affected different sensory attributes of supplemented bread Addition of OSP at the rate of $2 \%$ and $4 \%$ did not significantly alter the extent of grain formation in supplemented bread however $6 \%$ addition of OSP significantly improved the quality of the bread with respect to grain formation (Table 7). Likewise, addition of OSPE at the rate of $1 \%$ and $1.5 \%$ increased the quality of the bread as panelists assigned higher score to these breads. Color of the crumb remained unchanged and the judges could not discriminate OSP supplemented bread from control however supplementing OSPE @ $1.5 \%$ negatively affected the color of the crumb of the bread (Table7). Lower doses of OSP $(2 \%)$ added to the bread, did not significant affect the quality of the bread for mastication characteristics however the quality of the bread for this trait deteriorated in a dose dependent manner. Similar effect on mastication properties was noted on addition of OSPE @ $1 \%$ and 1.5\% (Table 7). Higher concentration $(6 \%)$ of OSP badly influenced the taste of the bread however judges still liked the supplemented bread. Taste was also negatively impacted on addition of OSPE @ 1 and $1.5 \%$ when compared with non-supplemented bread. Negative effect of OSPE on the aroma of the supplement bread was noticed albeit OSP also dampened the aromatic profile of the bread (Table 7). Onion skin has shown to bear gelling properties hence its use as thickening agent in the preparation of refined food products is on the rise, besides being a bulking agent, onion skin extracts exhibited the potential to influence enzymes activity in the food systems Given these bioactive role of onion skin extracts, researchers have suggested to supplement bread @ 3\% to produce cytostatic and anti-invasive effect on gastric cancer cells (Gawlik-Dziki et al., 2013; Schwartz et al., 1988). Our findings were in concurrence with those of Dziki et al. (2014) who supported application of vegetables waste fractions in various food preparations as sources of fibers, inorganic essential nutrients and phenolic antioxidants.

\section{CONCLUSION}

Escalating world population, food insecurities, environmental threats and climate change have been drastically impacting global food system which necessitates exploring alternative food sources as means to curb hunger in food in-secured peoples on the planet earth. Fruits and vegetable wastes, globally generated in huge quantities are not yet exploited for human benefit in the face of poverty, hunger and food insecurity. Given the compelling evidence of remarkable nutritional relevance of polyphenols, fiber, carotenoids, and minerals contained in vegetable wastes, food, pharmaceutical and other allied industries are not prepared to smartly leverage these food resources. Our study confirmed various vegetable wastes (carrot pomace, onion upper bulbs and peels from garlic, tomato $\&$ potato) to be notably carrying improved nutritional and functional properties suggesting their supplementation in food products for improved nutrition and nutraceutical potential. Moreover, there have been more avenues for research such as toxicological response, new techniques for extraction of bioactive compounds and marketing of vegetable wastes supplemented food and pharmaceutical products.

Acknowledgement: The data presented in this manuscript belong to the doctora dissertation of Mr. Muhammad Saad Hashmi, Ph.D. Scholar under the supervision of Dr. Saeed Akhtar, Director, Institute of Food Science \& Nutrition, Bahauddin Zakariya University, Multan, Pakistan.

Authors' contributions: Study design, its approval and critical revision of the manuscript was made by Saeed Akhtar, all laboratory analytics and data collection was performed by Muhammad Saad Hashmi while Tariq Ismail analyzed the data and created first draft of the manuscript.

Conflict of interest: The authors declare no conflict of interest.

\section{REFERENCES}

Adeola, A. A., Idowu, M. A., Adepoju, Y. D., Adesina, O. T., Oyewade, S. Olunlade, B. A., \& Ohizua, E. I. R. (2017). Chemical, functional and sensory properties of water yam, pigeonpea and carrot pomace flour blends. Annals Food Science and Technology, 18, 57 - 64 .

Agourram, A., Ghirardello, D., Rantsiou, K., Zeppa, G., Belviso, S., Romane, A. Oufdou, K., \& Giordano, M. (2013). Phenolic content, antioxidant potential, and antimicrobial activities of fruit and vegetable by-product extracts. International Journal of Food Properties, 16(5), $1092-1104$ https://dx.doi.org/10.1080/10942912.2011.576446.

Akhtar, S., Anjum, F. M., Rehman, S. U., Sheikh, M. A., \& Farzana, K. (2008) Effect of fortification on physico-chemical and microbiological stability of whole wheat flour. Food chemistry, 110(1), 113-119. https://dx.doi.org/10.1016/j.foodchem.2008.01.065.

Beatrice, O., \& Ifesan, T. (2017). Chemical composition of onion peel (Allium cepa) and its ability to serve as a preservative in cooked beef. International Journal of Science and Research Methodology, 7, 25-34.

Bello, M. O., Olabanji, I. O., Abdul-Hammed, M., \& Okunade, T. D. (2013). Characterization of domestic onion wastes and bulb (Allium cepa L.): fatty acids and metal contents. International Food Research Journal, 20, 2153-2158.

Ben-Othman, S., Jõudu, I., \& Bhat, R. (2020). Bioactives from agri-food wastes: Present insights and future challenges. Molecules, 25(3), 510. https://dx.doi.org/10.3390/molecules25030510.

Bhattacharjee, S., Sultana, A., Sazzad, M. H., Islam, M. A., Ahtashom, M., \& Asaduzzaman, M. (2013). Analysis of the proximate composition and energy values of two varieties of onion (Allium cepa L.) bulbs of different origin: A comparative study. International Journal of Nutrition and Food Sciences, 2(5), 246-253. https://dx.doi.org/ 10.11648/j.ijnfs.20130205.16.

Coman, V., Teleky, B. E., Mitrea, L., Martău, G. A., Szabo, K., Călinoiu, L. F., \& Vodnar, D. C. (2020). Bioactive potential of fruit and vegetable wastes In: Advances in Food and Nutrition Research, Academic Press, 91, pp. 157-225. de Sotillo, D. R., Hadley, M., \& Holm, E. T. (1994). Potato peel waste: stability and antioxidant activity of a freeze-dried extract. Journal of Food Science, 59(5), 1031-1033. https://dx.doi.org/10.1111/j.1365-2621.1994.tb08182.x.

Dillard, C. J., \& German, J. B. (2000). Phytochemicals: nutraceuticals and human health. Journal of the Science of Food and Agriculture, 80(12), 1744-1756. https://dx.doi.org/10.1002/1097-0010(20000915)80:12<1744::AID-

JSFA725>3.0.CO;2-W

Dinkecha, K., \& Muniye, M. (2017). Proximate Composition and Physicochemical Properties of Different Released and Improved Onion (Allium cepa L.) Bulbs Varieties. Food Science \& Quality Management, 67, 1 - 7 .

Dusuki, N. J. S., Abu Bakar, M. F., Abu Bakar, F. I., Ismail, N. A., \& Azman, M. I. (2019). Proximate composition and antioxidant potential of selected tubers peel. Food Research, 4, 121-126. https://dx.doi.org/10.26656/FR.2017.4(1).178 Dziki, D., Różyło, R., Gawlik-Dziki, U., \& Świeca, M. (2014). Current trends in the enhancement of antioxidant activity of wheat bread by the addition of plant materials rich in phenolic compounds. Trends in Food Science \& Technology, 40(1), 48-61. https://dx.doi.org/10.1016/j.tifs.2014.07.010.

Elbadrawy, E., \& Sello, A. (2016). Evaluation of nutritional value and antioxidant activity of tomato peel extracts. Arabian Journal of Chemistry, 9, S1010-S1018. https://dx.doi.org/10.1016/j.arabjc.2011.11.011.

Espinosa-Alonso, L. G., Valdez-Morales, M., Aparicio-Fernandez, X., MedinaGodoy, S., \& Guevara-Lara, F. (2020). Vegetable by-products. food wastes and 
by-products: nutraceutical and health potential (pp 223-266), John Wiley \& Sons.

Florkiewicz, A., Filipiak-Florkiewicz, A., Topolska, K., Cieślik, E., \& Kostogrys, R. B. (2014). The effect of technological processing on the chemical composition of cauliflower. Italian Journal of Food Science, 26, 275-281.

Food and Agriculture Organization of the United Nations - FAO. (2019). SAVE FOOD: Global 544 Initiative on Food Loss and Waste Reduction. Available at: http://www.fao.org/save-food/it/ 545 (accessed February 16, 2019).

Gawlik-Dziki, U., Świeca, M., Dziki, D., Baraniak, B., Tomiło, J., \& Czyż, J. (2013). Quality and antioxidant properties of breads enriched with dry onion (Allium cepa L.) skin. Food Chemistry, 138(2-3), 1621-1628. https://dx.doi.org/10.1016/i.foodchem.2012.09.151.

Gull, A., Prasad, K., \& Kumar, P. (2015). Effect of millet flours and carro pomace on cooking qualities, color and texture of developed pasta. LWT-Food Science and Technology, 63(1), 470-474. https://dx.doi.org/10.1016/j.lwt.2015.03.008.

Gumul, D., Ziobro, R., Noga, M., \& Sabat, R. (2011). Characterisation of five potato cultivars according to their nutritional and pro-health components. Acta Scientiarum Polonorum Technologia Alimentaria, 10(1), 77-81.

Harnly, J. M., Doherty, R. F., Beecher, G. R., Holden, J. M., Haytowitz, D. B. Bhagwat, S., \& Gebhardt, S. (2006). Flavonoid content of US fruits, vegetables, and nuts. Journal of agricultural and food chemistry,54(26), 9966-9977. https://dx.doi.org/10.1021/if061478a.

Ichikawa, M., Ryu, K., Yoshida, J., Ide, N., Kodera, Y., Sasaoka, T., \& Rosen, R. T. (2003). Identification of six phenylpropanoids from garlic skin as majo antioxidants. Journal of Agricultural and Food Chemistry, 51(25), 7313-7317. https://dx.doi.org/10.1021/jf034791a.

Iqbal, S., Haleem, S., Akhtar, M., Zia-ul-Haq, M., \& Akbar, J. (2008). Efficiency of pomegranate peel extracts in stabilization of sunflower oil under accelerated conditions. Food Research International, 41(2), 194-200. https://dx.doi.org/10.1016/j.foodres.2007.11.005.

Jaime, L., Mollá, E., Fernández, A., Martín-Cabrejas, M. A., López-Andréu, F. J., \& Esteban, R. M. (2002). Structural carbohydrate differences and potentia source of dietary fiber of onion (Allium cepa L.) tissues. Journal of Agricultural and Food Chemistry, 50(1), 122-128. https://dx.doi.org/10.1021/jf010797t.

Knoblich, M., Anderson, B., \& Latshaw, D. (2005). Analyses of tomato peel and seed byproducts and their use as a source of carotenoids. Journal of the Science of Food and Agriculture, 85(7), 1166-1170. https://dx.doi.org/10.1002/jsfa.2091 Korus, J., Witczak, T., Ziobro, R., \& Juszczak, L. (2015). Linseed (Linum usitatissimum L.) mucilage as a novel structure forming agent in gluten-free bread. LWT-Food Science and Technology,62(1), 257-264. https://dx.doi.org/10.1016/j.lwt.2015.01.040.

Latimer, Jr. (2019). Official methods of analysis (19th ed.). Gaithersburg M. D., USA. Association of Official Analytical Chemists.

Laura, A., Alvarez-Parrilla, E., \& Gonzalez-Aguilar, G. A. (2009). Fruit and vegetable phytochemicals: Chemistry, nutritional value and stability, John Wiley and Sons.

Li, Y., Guo, C., Yang, J., Wei, J., Xu, J., \& Cheng, S. (2006). Evaluation of antioxidant properties of pomegranate peel extract in comparison with pomegranate pulp extract. Food chemistry, 96(2), 254-260. https://dx.doi.org/10.1016/j.foodchem.2005.02.033.

Lu, Z., Wang, J., Gao, R., Ye, F., \& Zhao, G. (2019). Sustainable valorisation of tomato pomace: A comprehensive review. Trends in Food Science \& Technology, 86, 172-187. https://dx.doi.org/10.1016/j.tifs.2019.02.020.

Murakami, A., Ashida, H., \& Terao, J. (2008). Multitargeted cancer prevention by quercetin. Cancer letters, 269(2), 315-325. https://dx.doi.org/10.1016/j.canlet.2008.03.046.

Ncobela, C. N., Kanengoni, A. T., Hlatini, V. A., Thomas, R. S., \& Chimonyo, M. (2017). A review of the utility of potato by-products as a feed resource for smallholder pig production. Animal Feed Science and Technology, 227, 107-117. https://dx.doi.org/10.1016/j.anifeedsci.2017.02.008.

Nour, V., Panaite, T. D., Ropota, M., Turcu, R., Trandafir, I., \& Corbu, A. R. (2018). Nutritional and bioactive compounds in dried tomato processing waste. CyTA-Journal of Food, 16(1), 222-229. https://dx.doi.org/10.1080/19476337.2017.1383514.

Ogbonna, O. J., Udia, P. M., Abe, P. N., Omoregha, C. U., \& Anele, E. I. (2016). Phytochemical and proximate analysis, mineral and vitamin compositions of Allium Cepa bulb extract. Journal of Advanced Biomedical and Pharmaceutical Sciences, 3, 181-186.

Patel, K., \& Patel, D. K. (2019). The beneficial role of rutin, a naturally occurring flavonoid in health promotion and disease prevention: a systematic review and update. In: Bioactive Food as Dietary Interventions for Arthritis and Related Inflammatory Diseases, Academic Press, pp. 457-479.

Peñarrieta, J. M., Alvarado, J. A., Åkesson, B., \& Bergenståhl, B. (2008). Total antioxidant capacity and content of flavonoids and other phenolic compounds in canihua (Chenopodium pallidicaule): An Andean pseudocereal. Molecular $\begin{array}{llll}\text { nutrition } \quad \& \quad \text { food } & \text { research, 52(6), }\end{array}$ https://dx.doi.org/10.1002/mnfr.200700189.

Percival, S. S., Talcott, S. T., Chin, S. T., Mallak, A. C., Lounds-Singleton, A., \& Pettit-Moore, J. (2006). Neoplastic transformation of BALB/3T3 cells and cell cycle of HL-60 cells are inhibited by mango (Mangifera indica L.) juice and mango juice extracts. The Journal of Nutrition, 136(5), 1300-1304. https://dx.doi.org/10.1093/jn/136.5.1300.

Plaza, M., Amigo-Benavent, M., Del Castillo, M. D., Ibáñez, E., \& Herrero, M (2010). Facts about the formation of new antioxidants in natural samples after subcritical water extraction. Food Research International, 43(10), 2341-2348 https://dx.doi.org/10.1016/i.foodres.2010.07.036.

Prosky, L., Asp, N. G., Schweizer, T. F., Devries, J. W., \& Furda, I. (1988) Determination of insoluble, soluble, and total dietary fiber in foods and food products: interlaboratory study. Journal of the Association of Official Analytical Chemists, 71(5), 1017-1023. https://dx.doi.org/10.1093/jaoac/71.5.1017.

Sagar, N. A., Pareek, S., Sharma, S., Yahia, E. M., \& Lobo, M. G. (2018). Fruit and vegetable waste: bioactive compounds, their extraction, and possible utilization. Comprehensive Reviews in Food Science and Food Safety, 17(3), 512-531. https://dx.doi.org/10.1111/1541-4337.12330.

Sarkar, A., \& Kaul, P. (2014). Evaluation of tomato processing by-products: a comparative study in a pilot scale setup. Journal of Food Process Engineering, 37(3), 299-307. https://dx.doi.org/10.1111/jfpe.12086.

Schwartz, S. E., Levine, R. A., Weinstock, R. S., Petokas, S., Mills, C. A., \& Thomas, F. D. (1988). Sustained pectin ingestion: effect on gastric emptying and glucose tolerance in non-insulin-dependent diabetic patients. The American journal of clinical nutrition, 48(6), 1413 1417. https://dx.doi.org/10.1093/ajcn/48.6.1413.

Sharma, R., Oberoi, H. S., \& Dhillon, G. S. (2016). Fruit and vegetable processing waste: renewable feed stocks for enzyme production. In: Dhillon, G. S., \& Kaur, S., (Eds.), Agro-industrial wastes as feedstock for enzyme production: apply and exploit the emerging and valuable use options of waste biomass, London, UK, Academic Press, pp 23-59.

Silva, Y. P. A., Borba, B. C., Reis, M. G., Caliari, M., \& Ferreira, T. A. P. C. (2016). Tomato industrial waste as potential source of nutrients. In: International Technical Symposium Food: The Tree That Sustains Life, Vol. 51, pp 2108-3111. Singh, B. N., Singh, B. R., Singh, R. L., Prakash, D., Singh, D. P., Sarma, B. K., Upadhyay, G., \& Singh, H. B. (2009). Polyphenolics from various extracts/fractions of red onion (Allium cepa) peel with potent antioxidant and antimutagenic activities. Food and Chemical Toxicology,47(6), 1161-1167. https://dx.doi.org/10.1016/j.fct.2009.02.004.

Vaitkevičienè, N. (2019). A comparative study on proximate and mineral composition of coloured potato peel and flesh. Journal of the Science of Food and Agriculture, 99(14), 6227-6233. https://dx.doi.org/10.1002/jsfa.9895.

Yoon, K. Y., Cha, M., Shin, S. R., \& Kim, K. S. (2005). Enzymatic production of a soluble-fibre hydrolyzate from carrot pomace and its sugar composition. Food Chemistry, 92(1), 151-157. https://dx.doi.org/10.1016/j.foodchem.2004.07.014.

Zhang, Y., Liu, X., Ruan, J., Zhuang, X., Zhang, X., \& Li, Z. (2020). Phytochemicals of garlic: Promising candidates for cancer therapy. Biomedicine \& Pharmacotherapy, 123, 109730. https://dx.doi.org/10.1016/j.biopha.2019.109730.

Ziamajidi, N., Nasiri, A., Abbasalipourkabir, R., \& Sadeghi Moheb, S. (2017). Effects of garlic extract on TNF- $\alpha$ expression and oxidative stress status in the kidneys of rats with STZ+ nicotinamide-induced diabetes. Pharmaceutical biology, 55(1), 526-531. https://dx.doi.org/10.1080/13880209.2016.1255978.

Zoair, A. S. A., Attia, R. S., Abou Garbia, H. A., \& Youssef, M. (2016) Utilization of orange, banana and potato peels in formulating functional cupcakes and crackers. Alexandria Journal of Food Science \& Technology, 13, 11-8 https://dx.doi.org/10.12816/0038409. 